\title{
COMPARATIVE STUDY OF STRESS AND STRESS RELATED FACTORS IN MEDICAL AND ENGINEERING COLLEGES OF A SOUTH INDIAN CITY
}

\author{
Maseer Khan', Ayesha Fatima², Mohammed Shanawaz ${ }^{3}$, Mobeena Fathima $^{4}$, Anjali Mantri ${ }^{5}$ \\ ${ }^{1}$ Associate Professor, Department of Epidemiology, Faculty of Public Health and Tropical Medicine, Jazan University, \\ Kingdom of Saudi Arabia. \\ ${ }^{2}$ Assistant Professor, Department of Anatomy, Malla Reddy Medical College, Hyderabad, Telangana. \\ ${ }^{3}$ Assistant Professor, Department of Health Education and Promotion, Jazan University, Kingdom of Saudi Arabia. \\ ${ }^{4}$ MBBS Final Year Student, Katuri Medical College \& Hospital, Guntur, Andhra Pradesh, India. \\ ${ }_{5}^{5}$ MBS Final Year Student, Katuri Medical College \& Hospital, Guntur, Andhra Pradesh, India.
}

\section{ABSTRACT}

\section{BACKGROUND}

The process of professional education is often stressful. Various studies across the globe have emphasized that students undertaking professional courses, such as medical and engineering studies are subjected to higher stress. Excessive stress could lead to psychological problems like depression, anxiety and also it may cause suicides.

\section{OBJECTIVES OF STUDY}

- To assess the prevalence of stress among medical and engineering $11^{\text {st }}$ year students.

- To study the association of stress with various academic, social and health-related factors, in the professional courses like medical and engineering.

- $\quad$ To compare the factors causing stress in both medical and engineering students.

\section{METHODOLOGY}

Place of Study: Katuri Medical College and Hospital, Guntur.

\section{SAMPLE SIZE}

100 medical and 100 engineering students A pre-tested, self-administered questionnaire was used as the study instrument. It was developed with the help of published literature and finalized after a pilot study. The questionnaire was divided into three sections. First section includes the collection of Sociocultural and demographic data. Second section consists of effect of academic stressors on the life of the subject. Third section includes effect of health, life style and environmental stressors. In health, Zung Depression scale was utilized in scoring the depression levels in the study subjects.

\section{Study Period}

Month of April 2015. Software Used: MS Office, EPI Info 2002.

\section{RESULTS}

In the present study in medical course, $63 \%$ were found to be females and $37 \%$ were found to be males. In engineering, $54 \%$ were found to be males and $46 \%$ were found to be females. Respondents were belonging to the age group 18-22 years in both medical and engineering courses; $62 \%$ of medical students, $36 \%$ of engineering students were witnessing stress in their lives.

\section{DISCUSSION}

In the present study, stress was more in medical course than engineering owing to the overloaded syllabus. It is observed in the study that academic factors do have much impact on the life of the students.

\section{CONCLUSION}

Stress reducing techniques need to be encouraged in professional courses and counsellors for the effective addressing and solving the problems is required in all professional courses.

\section{KEYWORDS}

Stress, Medical Students, Engineering Students, Zung Depression Scale.

HOW TO CITE THIS ARTICLE: Khan M, Fatima A, Shanawaz M, et al. Comparative study of stress and stress related factors in medical and engineering colleges of a South Indian City. J. Evolution Med. Dent. Sci. 2016;5(48):3053-3056, DOI: $10.14260 /$ jemds/2016/711

Financial or Other, Competing Interest: None.

Submission 13-04-2016, Peer Review 23-05-2016,

Acceptance 30-05-2016, Published 14-06-2016.

Corresponding Author:

Dr. Maseer Khan,

Associate Professor, Department of Epidemiology,

Faculty of Public Health and Tropical Medicine,

Jazan University, Kingdom of Saudi Arabia.

E-mail:drmaseerkhan@gmail.com,maseerk@jazanu.edu.sa DOI: $10.14260 /$ jemds $/ 2016 / 711$

\section{INTRODUCTION}

Stress is an essential and inevitable concomitant of daily living. Essential because without some stress people will become listless and dispirited, and inevitable because it relates to any external event, be it pleasurable or anxietyproducing. Severe stress has been correlated with coronary disease, respiratory problems, backaches, high blood pressure and other psychosomatic illnesses, to the extent that for most people stress is a loaded term that connotes 
unhealthy or harmful conditions, i.e. a disease or illness. In truth, however, stress can also motivate and invigorate and enable people to achieve far more than they thought themselves capable of doing. ${ }^{1}$

Stress can be defined as 'any challenge to homeostasis,' or to the body's internal sense of balance. ${ }^{2}$ Stress can manifest itself either as eustress or as distress. Eustress, literally translated as 'good stress,' is a positive form of stress that motivates an individual to continue working. It is when this stress is no longer tolerable and/or manageable that distress manifests. Distress or 'bad stress,' is the point at which the good stress becomes too much to bear or cope with. Some signals that this change has occurred are when tension begins to build and there is no longer any fun in the challenge or there seems to be no relief or end in sight. This kind of stress is well-known and may lead to poor decision-making. The general characteristics of a person in distress are: being overaroused; tense or unable to relax; touchy, easily upset or irritable; easily startled or fidgety, and demonstrating intolerance of any interruption or delay. Excessive stress results in an increased prevalence of psychological problems like depression, anxiety, substance abuse and suicide ideation..$^{2,3}$ Stress may foster anxiety, substance abuse, burnouts leading to abandonment of studies, depression and even suicidal ideation. ${ }^{4}$

In this world, college students face more stress than anyone. Various studies around the globe have emphasized that students studying in medical, dental and engineering courses experience higher stress owing to the academic schedule of the courses. ${ }^{5}$ A student of Medical and Engineering courses has to read many hours a day routinely to understand vast field of study. Family and society has very high expectations from them. ${ }^{6}$

Many researchers have studied the importance of various academic factors in the development of stress. Johnson's research (1978) revealed nine major categories of student stress and his findings are supported by the results of several later studies. These categories are: instruction, competition, and organization of time, adjustment to college, administrative problems, social adjustment, finances, housing and transportation. ${ }^{7}$

However, the studies are very less on this topic in India, especially on populations in smaller cities. Engineering students have examinations per semester, whereas in medicine examinations are held annually. Theoretically, the higher frequency of examinations should lead to a higher prevalence of stress among engineering students, but reason being vast syllabus and demanding schedule, Minimal opportunity to relax and recreate, Academic pressure, Perfectionist standards stress is found to be more in Medical students.

The present study was undertaken in order to assess the prevalence of stress among students of medical and engineering colleges. The association of stress with various academic, social and health-related factors was seen in private medical and engineering colleges of Guntur City, Andhra Pradesh, India.

\section{AIM OF THE STUDY}

A comparative study of stress and stress related factors in Private Medical and Engineering Colleges of Guntur, A.P., India.

\section{OBJECTIVES OF STUDY}

1. To assess the prevalence of stress among medical and engineering $1^{\text {st }}$ year students.

2. To study the association of stress with various academic, social and health-related factors in the professional courses like medical and engineering.

3. To compare the factors causing stress in both medical and engineering students.

\section{MATERIAL AND METHODS \\ Place of Study \\ 1. Katuri Medical College and Hospital, Guntur, A.P. \\ 2. RVR and JC College of Engineering, Guntur, A.P.}

\section{Sample Size}

First year students of both colleges; 100 medical and 100 engineering students.

\section{Sampling Method}

In the Guntur City, there are 3 Medical colleges and 50 Engineering colleges from which 1 medical and 1 engineering college selected randomly by lottery method.

Convenient sample of 100 was taken from the selected Medical and Engineering Colleges.

\section{Study Period}

Month of April 2015.

\section{Software Used}

MS Office, EPI Info 2002.

A pre-tested, self-administered questionnaire was used as the study instrument. It was developed with the help of published literature and finalized after a pilot study. The questionnaire was divided into three sections.

- First section includes the collection of Sociocultural and Demographic data.

- Second section consists of effect of academic stressors on the life of the subject.

- Third section includes effect of health, life style and environmental stressors.

In Health Zung Depression scale. ${ }^{8}$ was utilized in scoring the depression levels in the study subjects.

\section{Zung's Self Rating Scale for Depression}

This scale was preferred to others, as this tool evaluates depression in normal non-psychotic individuals and has been time tested.

This scale assesses the perceived feelings of the students regarding their emotional status. The test form was labelled as "section three," as it is important that respondents be unaware that it is a depression scale. The tool consists of 20 items with scale ranging from 1 to 4 . The total score was the summation of all scores. The value ranges from 20 to 80 . Stress was considered as a continuous variable ranging from low-to-moderate to high degree of experienced feeling. A high degree of stress was reflected in high scores on the Zung's scale and a low degree was reflected in low scores on this scale. Score more than or equal to 40 was considered as stress.

Ethical approval of the study was taken and the students were contacted after their lectures. The nature and purpose of the study was explained in detail and willing students over 
18 years old were provided with questionnaires. The principal investigator was present while the students completed the questionnaire. Absolute privacy and a mental comfort zone were maintained for each individual student while answering the questionnaire. On completion of the questionnaire, participants were requested to submit the questionnaire.

\section{RESULTS}

\section{Demographic Data}

The mean age for engineering students was $18.16 \pm 0.545$ years and for medicine $18.52 \pm 0.703$ years. Male students (74\%) dominated in engineering when compared with medical (44\%) students. Most of the medicine students (82\%) hail from urban area than compared to engineering students (42\%). Similar results were seen in a study done by Vivek B et al. ${ }^{9}$ In both medicine (82\%) and engineering students (91\%), Hindus dominated in number; $56 \%$ and $24 \%$ in engineering and medicine students were residing in hostels and $55 \%$ and $74 \%$ were residing with families respectively. Maximum families were of nuclear type.

Majority of parents of medical students were graduates (74\% in the group of fathers and $51 \%$ in the group of mothers). When comparison was done between father's education of medicine and engineering student's professionals were found to be more in medicine group.

When compared between medicine and engineering student's family's income, it was found that medicine students were found to be from upper class than engineering students (Based on Modified Kuppuswamy scale).

\begin{tabular}{|c|c|c|c|c|}
\hline Variable & & \begin{tabular}{|c} 
Engineering \\
Students \\
$(n=100)$
\end{tabular} & $\begin{array}{l}\text { Medical } \\
\text { Students } \\
(\mathrm{n}=100)\end{array}$ & $\begin{array}{c}P \\
\text { value }\end{array}$ \\
\hline $\begin{array}{c}\text { Age } \\
\text { (In years) } \\
\text { Mean } \pm \text { SD }\end{array}$ & & $\begin{array}{c}18.16 \pm \\
0.545\end{array}$ & $\begin{array}{c}18.52 \pm \\
0.703\end{array}$ & \\
\hline \multirow{2}{*}{ Sex } & Male & 74 & 44 & \multirow{2}{*}{0.0001} \\
\hline & Female & 26 & 56 & \\
\hline \multirow{3}{*}{ Area } & Rural & 57 & 17 & \multirow{3}{*}{0.0001} \\
\hline & Urban & 42 & 82 & \\
\hline & Tribal & 1 & 1 & \\
\hline \multirow{3}{*}{ Religion } & Hindu & 91 & 82 & \\
\hline & Muslim & 2 & 8 & \\
\hline & Christian & 7 & 10 & \\
\hline $\begin{array}{l}\text { Present } \\
\text { Residing in } \\
\text { Hostel }\end{array}$ & & 56 & 24 & \\
\hline $\begin{array}{l}\text { Residing } \\
\text { with Family }\end{array}$ & & 55 & 75 & \\
\hline Family type & Nuclear & 93 & 88 & \\
\hline $\begin{array}{l}\text { Father's } \\
\text { education }\end{array}$ & $\begin{array}{c}\text { Graduation and } \\
\text { above }\end{array}$ & 44 & 74 & 0.0001 \\
\hline $\begin{array}{l}\text { Mother's } \\
\text { education }\end{array}$ & $\begin{array}{c}\text { Graduation and } \\
\text { above }\end{array}$ & 30 & 51 & 0.002 \\
\hline $\begin{array}{c}\text { Fathers } \\
\text { occupation }\end{array}$ & Professional & 46 & 69 & 0.003 \\
\hline $\begin{array}{l}\text { Mother's } \\
\text { occupation }\end{array}$ & House wife & 78 & 75 & \\
\hline $\begin{array}{l}\text { Family } \\
\text { income }\end{array}$ & $\begin{array}{c}\text { Earning more } \\
\text { than } 30375 \text { per } \\
\text { month }\end{array}$ & 34 & 64 & 0.0001 \\
\hline \multicolumn{5}{|c|}{$\begin{array}{l}\text { Table 1: Socio-Demographic Data of } \\
\text { Medical and Engineering Students }\end{array}$} \\
\hline
\end{tabular}

\begin{tabular}{|c|c|c|c|c|}
\hline Course & Normal & $\begin{array}{c}\text { Mild } \\
\text { Depression }\end{array}$ & $\begin{array}{c}\text { Moderate } \\
\text { Depression }\end{array}$ & Total \\
\hline Engineering & 64 & 34 & 2 & 100 \\
\hline Medicine & 38 & 51 & 11 & 100 \\
\hline Total & $\mathbf{1 0 2}$ & $\mathbf{8 5}$ & $\mathbf{1 3}$ & $\mathbf{2 0 0}$ \\
\hline
\end{tabular}

Table 2: Table showing Depression in the Study Subjects (Based on Zung Depression Scale)

Chi square $=13.53, \mathrm{df}=1, \mathrm{p}=0.0002$

In engineering students $64 \%$ were found to be normal in comparison with medicine (38\%) and this was found to be highly statistical significant.

In MBBS students, $11 \%$ of moderate depression was found and only $2 \%$ of moderate depression found in engineering students.

\begin{tabular}{|c|c|c|c|}
\hline Course & \multicolumn{2}{|c|}{ Examination Phobia } & \multirow{2}{*}{ Total } \\
\hline Engineering & Yes & No & \\
\hline Medicine & 38 & 62 & 100 \\
\hline Total & 54 & 46 & 100 \\
\hline
\end{tabular}

Table 3: Table showing Examination Phobia in Medical and Engineering Students

Chi square $=5.13, \mathrm{df}=1, \mathrm{p}=0.02$ significant.

In the study population, students studying MBBS (54\%) were found to have more examination phobia when compared with engineering (38\%) and this was found to be statistically significant.

\begin{tabular}{|c|c|c|}
\hline Caste Discretion & Frequency & Percent \\
\hline Yes & 28 & 14 \\
\hline No & 172 & 86 \\
\hline Total & 200 & 100 \\
\hline
\end{tabular}

$14 \%$ of study population said the caste discretion is having effect on mental tension.

\begin{tabular}{|c|c|c|}
\hline \multirow{2}{*}{ Course } & \multicolumn{2}{|c|}{ Academic Stressors } \\
\cline { 2 - 3 } & Yes & No \\
\hline Engineering & 32 & 68 \\
\hline Medicine & 63 & 37 \\
\hline Table 5: Table showing the Effect of Academics \\
Causing Stress in the Study Subjects \\
\hline
\end{tabular}

Chi square $=19.27, \mathrm{df}=1, \mathrm{p}=0.00001$ significant

Academic stressors were captured with the help of 8 questions and in that who scored more than 5 were treated as having stress. In this table, it was found that medicine students do have more academic related stress when compared with engineering.

\begin{tabular}{|c|c|c|c|}
\hline Course & Mean & $\mathbf{N}$ & Standard Deviation \\
\hline Engineering & 43.75 & 100 & 6.45 \\
\hline Medicine & 49.55 & 100 & 6.53 \\
\hline \multicolumn{4}{|c|}{ Table 6: Table showing Mean depression } \\
score rating in the study subjects \\
\hline
\end{tabular}


According to Zung Depression Scale, 20-44 Score Treated as Normal

45-59 - mild depression.

60-69 - moderate depression.

$>70$ - severe depression.

In medicine mean depression scale was high when compared with engineering students.

\section{DISCUSSION}

Stress appears to be universally prevalent entity in all students regardless of their age, sex, education, parent's occupation. Students from the two fields of education are exposed to stress; however, it seems that medical students are more prone to the development of stress compared to engineering students due to overloaded studies. In a similar fashion, Al-Dabal et al observed a greater prevalence of stress in medical students in comparison with non-medical students in Saudi Arabia. ${ }^{10}$ Considerable number of medical students were found to have moderate depression, which may warrant clinical attention. It may be that longer duration of study and greater duration required to complete professional degree coupled with higher expectations from parents of same background. ${ }^{11}$ poses a greater degree of stress in Medicine. Depression score was found to be almost same in both males and females and this shows that only academic stressor are playing major role in causing stress. Academic stressors play a major role in causing stress in professional courses. Researches done by Al Dabal et $\mathrm{al}^{11}$ and Behere et al ${ }^{12}$ have showed the similar results with academics playing a role as stressor. Examination phobia was found to be more in medicine than engineering owing to the vast and difficult subject in medicine. It was very unfortunate to get $14 \%$ of people saying caste discretion causing stress. In this modern era, still we are witnessing this social evil and that too in professional courses.

\section{CONCLUSIONS}

Academic factors are found to be the most important stressors. So there is a pressing need for definite measures to decrease substantially the burden of stress on the students. Teaching techniques and college environments should be adapted to the needs of the students. The productive utilisation of existing student welfare systems, development of more 'student-friendly' environments and regular periodic extracurricular activities with universal participation can prove to be useful stress-busters. Stress reducing techniques need to be encouraged in professional courses and counsellors for the effective addressing and solving the problems is required in all professional courses. Parents and students should be aware that unnecessary expectations about academics can lead to stress. Finally, regular study habits and adequate preparation can help students to avoid stress.

\section{ACKNOWLEDGEMENT}

The authors would like to thank Dr. Mohamed AL-Malki, Dean of Public Health and Tropical Medicine, Jazan University for giving his support and encouragement in completing the Article. The authors would also like to acknowledge with much appreciation all the students who participated in this study and their respective institutions.

\section{REFERENCES}

1. Benjamin, Libby. Understanding and managing stress in the academic world. An ERIC/CAPS Digest ED291017, 1987. http://www.ericdigests.org/pre-927/stress.htm cited on 29/03/16.

2. Bansal CP, Bhave SY. Stress in adolescents and its management. In: Bhave SY, editor. Bhave's textbook of adolescent medicine. New Delhi: jaypee brothers medical publishers 2006;844-53.

3. Arria AM, O'Grady KE, Caldeira KM, et al. Suicide ideation among college students: a multivariate analysis. Arch Suicide Res 2009;13(3):230-46.

4. Dahlin M, Nilsson C, Stotzer E, et al. Mental distress, alcohol use and help-seeking among medical and business students: a cross-sectional comparative study. BMC Med Educ 2011;11:92.

5. Sharifirad G, Marjani A, Abdolrahman C, et al. Stress among isfahan medical sciences students. J Res Med Sci 2012;17(4):402-6.

6. Modi K, Kumar D. Anxiety and depression in medical students and its association with coping methods adopted by them. IJRRMS 2013;3(2):20-2.

7. Benjamin, Libby. Understanding and managing stress in the academic world. An ERIC/CAPS digest 1987-12-00. http://files.eric.ed.gov/fulltext/ED291017.pdf.

8. http://healthnet.umassmed.edu/mhealth/ZungSelfRate dDepressionScale.pdf.

9. Vivek B Waghachavare, Girish B Dhumale, Yugantara R Kadam, et al. A study of stress among students of professional colleges from an urban area in India. Sultan Qaboos University Med J 2013;13(3):429-36.

10. Al-Dabal BK, Koura MR, Rasheed P, et al. A comparative study of perceived stress among female medical and non-medical university students in dammam, saudi Arabia. Sultan Qaboos Univ Med J 2010;10(2):231-40.

11. Nichols K. Practising what we preach. Psychol 1988;1:50-1.

12. Behere SP, Yadav R, Behere PB. A comparative study of stress among students of medicine, engineering, and nursing. Indian J Psychol Med 2011;33(2):145-8. 